\title{
Detection of invA virulence gene of multidrug-resistant Salmonella species isolated from the cloacal swab of broiler chickens in Blitar district, East Java, Indonesia
}

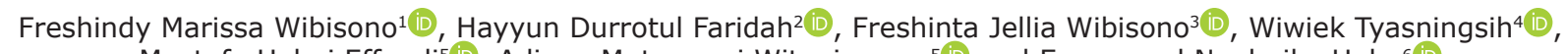
Mustofa Helmi Effendi ${ }^{5}$, Adiana Mutamsari Witaningrum ${ }^{5}$ (D) and Emmanuel Nnabuike Ugbo 6 (i)

1. Department of Veterinary Public Health, Faculty of Veterinary Medicine, Universitas Airlangga, Surabaya, Indonesia;

2. Department of Biology, Faculty of Science and Technology, Universitas Airlangga, Surabaya, Indonesia;

3. Department of Veterinary Public Health, Faculty of Veterinary Medicine, Wijaya Kusuma University Surabaya, Surabaya, Indonesia; 4. Department of Veterinary Microbiology, Faculty of Veterinary Medicine, Universitas Airlangga, Surabaya, Indonesia; 5. Department of Veterinary Public Health, Faculty of Veterinary Medicine, Universitas Airlangga, Surabaya, Indonesia; 6. Department of Applied Microbiology, Ebonyi State University, Abakaliki, Nigeria.

Corresponding author: Mustofa Helmi Effendi, e-mail: mheffendi@yahoo.com

Co-authors: FMW: freshindymw@gmail.com, HDF: hayyun.durrotul.faridah-2019@fst.unair.ac.id,

FJW: freshinta.uwks@gmail.com, WT: witya_kh@yahoo.com, AMW: adiana_mutam@yahoo.co.id, ENU: ugbonuel2001@yahoo.com

Received: 23-06-2021, Accepted: 02-11-2021, Published online: 19-12-2021

doi: www.doi.org/10.14202/vetworld.2021.3126-3131 How to cite this article: Wibisono FM, Faridah HD, Wibisono FJ, Tyasningsih W, Effendi MH, Witaningrum AM, Ugbo EN (2021) Detection of invA virulence gene of multidrug-resistant Salmonella species isolated from the cloacal swab of broiler chickens in Blitar district, East Java, Indonesia, Veterinary World, 14(12): 3126-3131.

\begin{abstract}
Background and Aim: The increasing number of multidrug-resistant (MDR) Salmonella species on poultry farms in Indonesia has caused concern regarding human health. This study was conducted to determine the presence of the virulence gene invA in MDR Salmonella species isolated from the cloacal swab of broiler chickens in Blitar district, East Java Province, Indonesia.

Materials and Methods: Cloacal swab samples were collected by purposive sampling from 15 farms in four districts. Isolation and identification of bacteria were performed using standard microbiological techniques. Confirmation of MDR isolates was done using five different classes of antibiotics, including the beta-lactam, aminoglycoside, fluoroquinolone, phenicol, and monobactam groups. An antibiotic susceptibility test was conducted using the Kirby-Bauer disk diffusion method, and a polymerase chain reaction method was used to screen for the presence of invA.
\end{abstract}

Results: It was observed that $32.26 \%(50 / 155)$ of the samples were positive for Salmonella species. Of these 50 Salmonella isolates, 7 (14\%) were identified as MDR strains. An important finding was the detection of invA in all the seven MDR Salmonella strains (100\%) isolated from the cloacal swab of broiler chickens in Blitar district, East Java Province.

Conclusion: Veterinarians have an extremely important role in monitoring the use of antibiotics in farm animals to mitigate the rapid spread of MDR organisms in our environment, which can otherwise cause serious economic losses and also public health issues.

Keywords: broiler chicken, invA gene, multidrug-resistant, public health, Salmonella.

\section{Introduction}

Salmonella species have been the major cause of foodborne diseases in several countries in the past 100 years [1-3]. It has been reported worldwide that there are 1.6 million cases of typhoid fever, 1.3 billion cases of gastroenteritis, and 3 million deaths due to Salmonella species [4]. Salmonellosis is a disease caused by the pathogenic agent Salmonella spp. Salmonellosis has been categorized as an important public health zoonosis [5-7] with a high morbidity rate and is difficult to prevent [8,9]. Salmonella species

Copyright: Wibisono, et al. Open Access. This article is distributed under the terms of the Creative Commons Attribution 4.0 International License (http://creativecommons.org/licenses/ by/4.0/), which permits unrestricted use, distribution, and reproduction in any medium, provided you give appropriate credit to the original author(s) and the source, provide a link to the Creative Commons license, and indicate if changes were made. The Creative Commons Public Domain Dedication waiver (http:// creativecommons.org/publicdomain/zero/1.0/) applies to the data made available in this article, unless otherwise stated. have several virulence factors that are important in the process of infection in the host and spread of disease. Most virulence factors are located in chromosomal genes known as Salmonella pathogenicity islands (SPIs). SPIs are essential for invasion and proliferation in host cells $[10,11]$.

Chromosomal virulence genes comprise invA, $\operatorname{inv} \mathrm{E}, \operatorname{him} \mathrm{A}$, and $p h o \mathrm{P}$, which are included among the target genes for polymerase chain reaction (PCR) amplification in Salmonella spp. [12,13]. Salmonella spp. harbor invA that plays a role in causing illness. More than $50 \%$ of these serotypes are Salmonella enterica, which accounts for the majority of human Salmonella infections [3]. This gene is located in the area of SPI, which has an operon that functions as a repository for genetic information [14]. invA from Salmonella spp. contains a unique DNA sequence and has been confirmed to be a suitable PCR target gene for the detection of Salmonella spp. [15]. This gene encodes proteins in 
bacterial cell membranes that are required for invasion into host epithelial cells [16]. In vitro amplification of DNA by the PCR method is an accurate tool for microbiological diagnosis [17].

Blitar has the largest chicken farms in East Java province, which consists of layer and broiler farms [18]. This high population enables the development of several diseases. The incidence of infection with Salmonella species is caused by contact with animals $[9,19]$. Infection can be acquired by both direct and indirect contact with animals [20]. Due to the increasing incidence of infectious diseases, antibiotic use has become the most predominant strategy in health services [21,22]. Such high use of antibiotics has resulted in an increase in antibiotic resistance [23].

This study was conducted to determine the presence of the virulence gene invA in multidrug-resistant (MDR) Salmonella species isolated from the cloacal swab of broiler chickens in Blitar district, East Java Province, Indonesia.

\section{Materials and Methods}

\section{Ethical approval}

Ethical approval was not necessary. However, cloacal swab samples were collected as per the standard collections method without any harm to the broiler.

\section{Study period and location}

This research was conducted from October 2020 to February 2021. Samples were collected from 15 broiler farms in Blitar district. The farms are located in four sub-districts, namely Ponggok, Garum, Selopuro, and Selorejo sub-districts. Samples were processed at Laboratory of Department of Veterinary Public Health, Faculty of Veterinary Medicine, Universitas Airlangga.

\section{Sample collection}

The sampling technique was carried out by purposive sampling from broiler farms that had been determined by the researchers with criteria, namely, information from the relevant agencies, and broiler chickens that had clinical digestive symptoms such as diarrhea, abnormal stool color, weakness, and dirty parts around the cloaca. Samples were taken from the cloacal swab of broiler chickens in Blitar district [24]. The sample size used was 155 cloacal swab samples from 15 broiler farms on four subdistricts (Figure-1) [25].

\section{Bacterial isolates}

Bacterial testing included isolation and identification of Salmonella isolates. Bacterial isolation was conducted by collecting a suspension using an inoculation loop sterilized under a Bunsen burner fire.

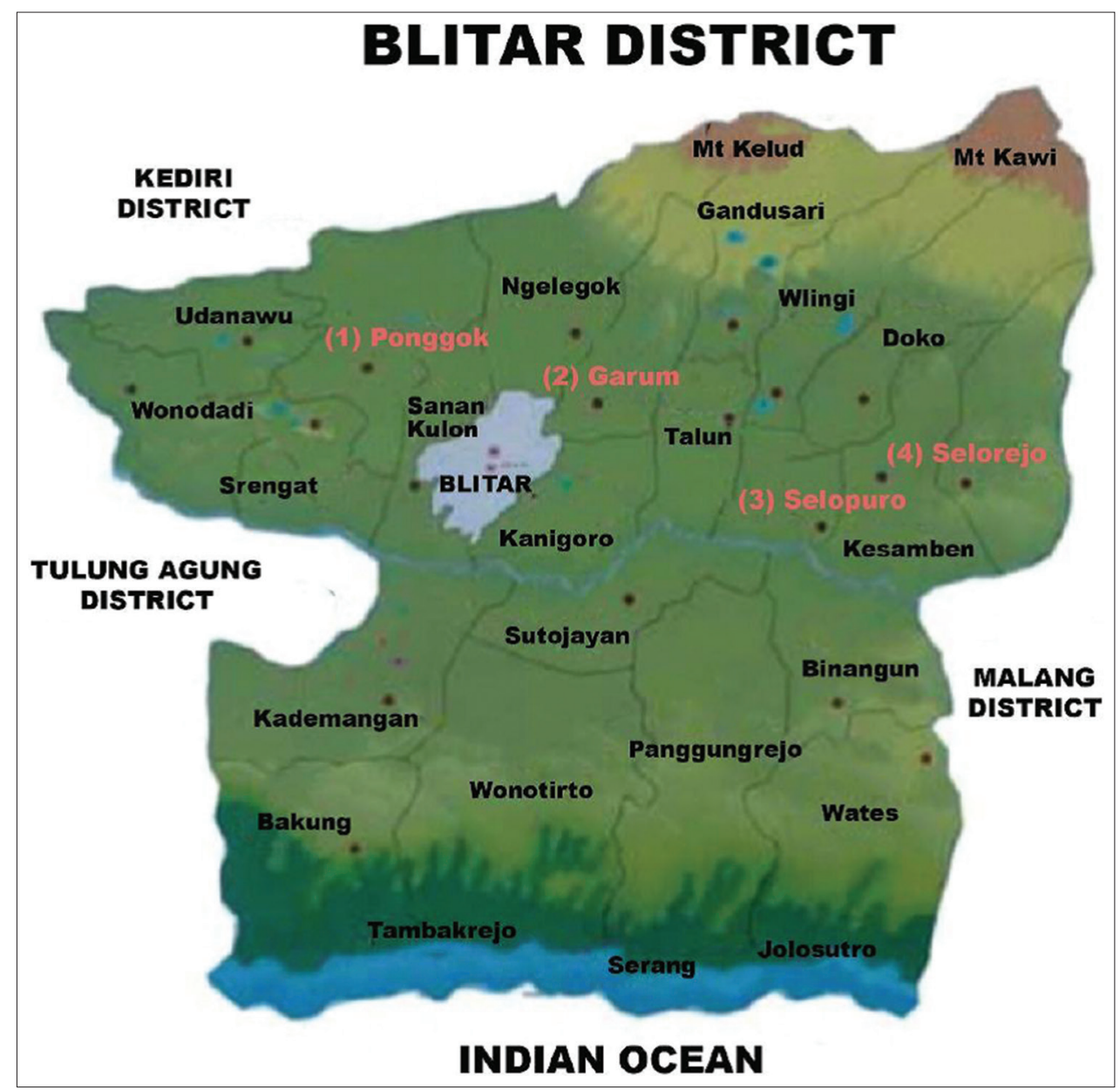

Figure-1: Map of the distribution of sampling in Blitar district. (1) Ponggok subdistrict; (2) Garum subdistrict; (3) Selopuro subdistrict; and (4) Selorejo subdistrict [25]. 
The suspension was implanted in Salmonella-Shigella agar (Figure-2). Salmonella growth produces a transparent or colorless colony with a black center due to the formation of $\mathrm{H}_{2} \mathrm{~S}$ gas. Presumptive Salmonella was placed on bismuth sulfite agar media. Bismuth sulfite is a selective medium for the isolation of Salmonella in the laboratory and is generally used for the detection of Salmonella species.

\section{Antibiotic sensitivity test}

All Salmonella spp. isolates were subjected to the antibiotic sensitivity test, and confirmation of MDR isolates was done using antibiotic sensitivity tests to five different classes of antibiotics. The following antibiotic disks (Oxoid, England) were used: Beta-lactam (amoxicillin $10 \mathrm{~g}$ ), aminoglycoside (gentamicin $10 \mathrm{~g}$ ), quinolone (ciprofloxacin $5 \mathrm{~g}$ ), phenicol (chloramphenicol $30 \mathrm{~g}$ ), and monobactam (aztreonam $30 \mathrm{~g}$ ) groups.

\section{PCR amplification of invA}

All the MDR Salmonella spp. were tested for the presence of the virulence gene invA [26,27]. This gene is responsible for the virulence factor of

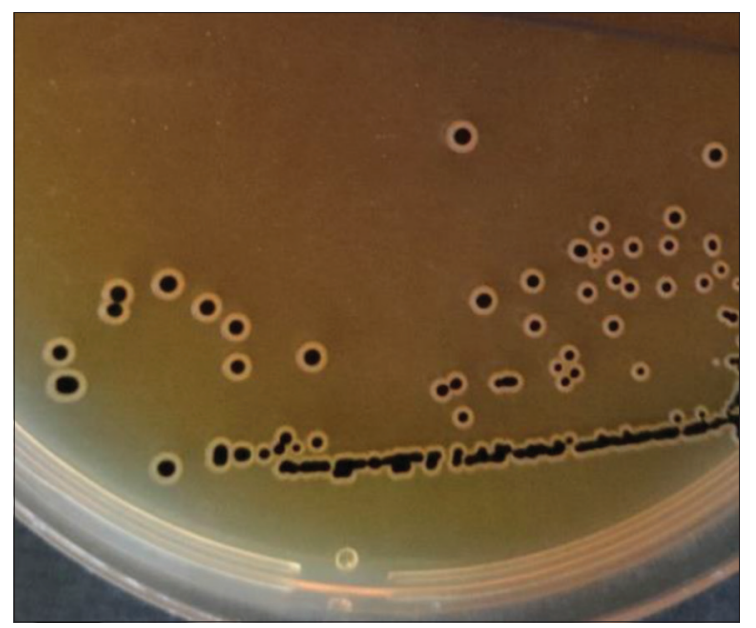

Figure-2: Pure colonies of Salmonella spp. on SSA media.

Table-1: Isolation and identification of Salmonella species on Blitar district.

\begin{tabular}{lccc}
\hline Subdistrict & Samples & Salmonella spp. & Percentage \\
\hline Ponggok & 53 & 15 & 28.30 \\
Garum & 25 & 15 & 60.00 \\
Selopuro & 51 & 14 & 27.45 \\
Selorejo & 26 & 6 & 23.08 \\
Total & 155 & 50 & 32.26 \\
\hline
\end{tabular}

Salmonella spp. The specific primers used to detect invA in Salmonella isolates have been previously published [16], which included the forward primer $5^{\prime}$ GTG AAA TTA TCG CCA CGT TCG GGC AA 3' and the reverse primer $5^{\prime}$ TCA TCG CAC CGT CAA AGG AAC C 3' (284 bp). This study was conducted at the Veterinary Public Health Laboratory, Faculty of Veterinary Medicine, Universitas Airlangga, and the Microbiology Laboratory of the Central Health Laboratory, Surabaya. In the PCR analysis, Escherichia coli isolate ATCC 25922 was used as a negative control, and Salmonella Paratyphi A isolate ATCC 9150 was used as a positive control, which had been previously tested for the presence of invA.

\section{Results and Discussion}

Salmonella species remains one of the major causes of foodborne diseases such as salmonellosis and other related diarrhea in several countries in the world [3]. The findings of this study indicated that $32.26 \%(50 / 155)$ of the samples were positive for Salmonella isolates (Table-1). The highest incidence occurred in Garum subdistrict $(60.00 \%)$, followed by Ponggok $(28.30 \%)$ and Selopuro $(27.45 \%)$ subdistricts, and the lowest incidence occurred in Selorejo subdistrict $(23.08 \%)$. These results indicated the presence of high infection with Salmonella spp. in Blitar district. The overall incidence is much higher than that of the previous studies, which reported an incidence of $3.2 \%$ in layer chickens and $12.4 \%$ in broiler chickens from five provinces in Java [28]; however, the incidence of salmonellosis in layer chicken farms in Sidrap district was $76.39 \%$ [29]. Our study findings indicate the need for increased attention toward an immediate follow-up by relevant policymakers as an effort to prevent the spread of zoonotic diseases [30]. Salmonellosis is a zoonotic disease caused by Salmonella spp., which can affect humans and animals. Indirect transmission can occur through contact with the environment around animals or with contaminated objects around poultry farms [6,31].

The high incidence of salmonellosis in Garum subdistrict compared to that in the other three subdistricts is due to the relatively low sanitation in poultry farms. In general, the farm is located behind the farmer's house. Field conditions showed the sewerage from the farmer's house is adjacent to the cage. Contamination and infection with Salmonella spp. on a farm with poor

Table-2: Multidrug resistance of Salmonella spp. on broiler chicken.

\begin{tabular}{|c|c|c|c|c|c|c|c|c|c|c|c|c|c|}
\hline \multirow[t]{2}{*}{ Location } & \multirow[t]{2}{*}{$\begin{array}{c}\text { Salmonella } \\
\text { spp. }\end{array}$} & \multicolumn{2}{|c|}{ Beta-lactam } & \multicolumn{2}{|c|}{ Aminoglycoside } & \multicolumn{2}{|c|}{ Quinolone } & \multicolumn{2}{|c|}{ Phenicol } & \multicolumn{2}{|c|}{ Monobactam } & \multicolumn{2}{|c|}{$\begin{array}{c}\text { Multidrug } \\
\text { resistant }\end{array}$} \\
\hline & & $\mathbf{R}$ & $\%$ & $\mathbf{R}$ & $\%$ & $\mathbf{R}$ & $\%$ & $\mathbf{R}$ & $\%$ & $\mathbf{R}$ & $\%$ & Total & $\%$ \\
\hline Ponggok & 15 & 5 & 33.3 & 4 & 26.7 & 3 & 20 & 2 & 13.3 & 0 & 0 & 0 & 0.00 \\
\hline Garum & 15 & 5 & 33.3 & 2 & 13.3 & 6 & 40 & 2 & 13.3 & 0 & 0 & 3 & 20.00 \\
\hline Selopuro & 14 & 8 & 57.1 & 4 & 28.6 & 11 & 78.6 & 0 & 0 & 0 & 0 & 3 & 21.43 \\
\hline Selorejo & 6 & 4 & 66.7 & 2 & 33.3 & 3 & 50 & 2 & 33.3 & 0 & 0 & 1 & 16.67 \\
\hline Total & 50 & 22 & 44 & 12 & 24 & 23 & 46 & 6 & 12 & 0 & 0 & 7 & 14 \\
\hline
\end{tabular}




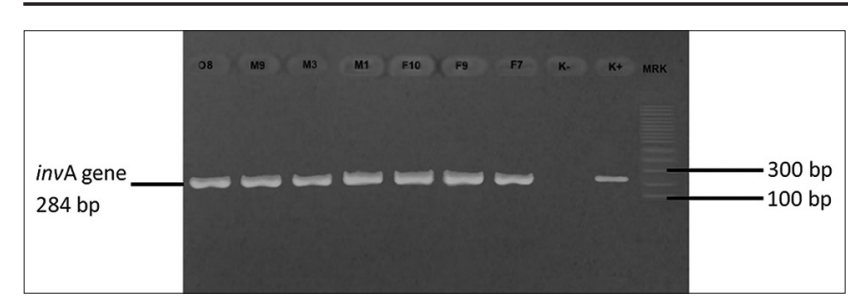

Figure-3: Gene invA of Salmonella spp. multidrug-resistant isolates. $\mathrm{K}+=$ Salmonella Paratyphi A ATCC 9150 as positive control; $\mathrm{K}-=E$. coli ATCC 25922 as negative control; $\mathrm{F} 7$, $\mathrm{F9}, \mathrm{F} 10, \mathrm{M1}$, M3, M9, and O8=Multidrug-resistant isolates.

sanitation can occur due to the spread of Salmonella spp. through contaminated feces, thereby contaminating feed, drinking water, and hatching eggshells [28].

Salmonellosis can be treated using antibiotics. The emergence of MDR Salmonella species has now received the attention of various researchers. MDR indicates the resistance of bacteria to three or more classes of antibiotics [32]. Such resistance to some of these antibiotics can occur due to the pattern of continuous use of antibiotics in the livestock industry as both treatment and feed additives and growth promoters. The continuous use of antibiotics is a triggering factor for high levels of antibiotic resistance [33,34].

In this study, quinolone and beta-lactam exhibited the highest yields of $46 \%$ and $44 \%$, respectively (Table-2). This is because these classes of antibiotics are often used in broiler farms in Blitar district. Fluoroquinolones have a very narrow safety range and are safe in low or high doses but for a short time. Continuous use for prolonged periods can cause side effects [35]. Beta-lactams are the most widely used class of antibiotics in both human clinical practice and veterinary medicine because they are broad-spectrum antibiotics and exhibit a very good level of safety [34]. Routine administration of broad-spectrum antibiotics is one of the supporting factors for the changing patterns of resistance to various antibiotics [36]. Cases of antibiotic resistance in bacteria can be caused by a lack of supervision on the use of antibiotics in farms, as $72.3 \%$ of farmers use antibiotics without veterinary supervision [37]. Risk factors such as the broiler breed, breeder education, type of partnership business, type of factory feed, veterinarian support in livestock rearing management, cage hygiene sanitation, chlorine treatment of drinking water, the existence of an antibiotic program, and reference to the use of antibiotics are positively associated with the incidence of MDR in chicken farms [38,39].

The findings of this study showed that seven Salmonella isolates were MDR) (Table-2), as they were resistant to three different classes of antibiotics. MDR is caused by the continuous use of one type of antibiotic by the farmers. However, no single isolate was collectively resistant to the same antibiotic class. The existence of a rotation program in the administration of antibiotics can prevent the incidence of antibiotic resistance. Hence, it is necessary to educate farmers on the use of different antibiotics or the rotation of antibiotics during disease treatment. The role of veterinarians is also extremely important in monitoring the use of antibiotics on farms. Antibiotics must be used wisely and in the correct dose, and not as a disease prevention strategy $[38,40,41]$.

Our results also confirmed the presence of the virulence gene invA in all the seven (100\%) MDR Salmonella isolates using invA-specific primers (Figure-3). In all these isolates, invA was successfully amplified at $284 \mathrm{bp}$. This finding indicated that it is difficult to treat salmonellosis caused by MDR isolates because they have the ability to be pathogenic as evidenced by the presence of invA. This gene encodes membrane proteins in bacteria that are responsible for invading host intestinal cells $[42,43]$. In Salmonella isolates, invA was located in SPI-1, which plays an extremely important role in the invasion of host epithelial cells. This gene is highly specific for most Salmonella species $[44,45]$. Salmonella spp. harbors numerous virulence factors, which is one of the causes for the high incidence of salmonellosis in humans and animals. Intensive use of antibiotics for salmonellosis treatment leads to the emergence of resistant bacteria. One of the best assays for identifying virulence genes is PCR [46,47].

\section{Conclusion}

In total, $32.26 \%(50 / 155)$ of the samples were positive for Salmonella species. Of the 50 isolates, $7(14 \%)$ were found to be MDR. The virulence gene invA was identified in all the seven MDR Salmonella strains $(100 \%)$ isolated from the cloacal swab of broiler chickens in Blitar district, East Java Province. Veterinarians have an extremely important role in monitoring the use of antibiotics in farm animals to mitigate the rapid spread of MDR organisms in our environment, which can otherwise cause serious economic losses and also public health issues.

\section{Authors' Contributions}

MHE, FMW, and FJW: Conceptualization. MHE, FMW, and HDF: Data curation. WT and AMW: Formal analysis. MHE and WT: Funding acquisition. FMW, HDF, and FJW: Investigation. MHE and AMW: Methodology. MHE and AMW: Project administration. MHE, FMW, and FJW: Resources. MHE and WT: Supervision. MHE, WT, and ENU: Validation. FMW and AMW: Visualization. MHE, FMW, and FJW: Writing original draft. MHE and ENU: Review and editing. All authors read and approved the final manuscript.

\section{Acknowledgments}

We would like to thank Blitar Animal Husbandry Office, Indonesia, for their help in the data collection used in this study. This study was funded by Universitas Airlangga, Indonesia (Grant number 420/ UN3.15/PT/2021). 


\section{Competing Interests} interests.

The authors declare that they have no competing

\section{Publisher's Note}

Veterinary World remains neutral with regard to jurisdictional claims in published map and institutional affiliation.

\section{References}

1. Dos Santos, A.M.P., Ferrari, R.G. and Conte-Junior, C.A. (2019) Factors in Salmonella Typhimurium: The sagacity of a bacterium. Curr. Microbiol., 76(6): 762-773.

2. Lee, K.M., Runyon, M., Herrman, T.J., Phillips, R. and Hsieh, J. (2015) Review of Salmonella detection and identification methods: Aspects of rapid emergency response and food safety. Food Control., 47(1): 264-276.

3. Wibisono, F.M., Wibisono, F.J., Effendi, M.H., Plumeriastuti, H., Hidayatullah, A.R., Hartadi, E.B. and Sofiana, E.D. (2020) A review of salmonellosis on poultry farms: Public health importance. Syst. Rev. Pharm., 11(9): 481-486.

4. Pui, C.F., Wong, W.C., Chai, L.C., Tunung, R., Jeyaletchumi, P., Noor Hidayah, M.N., Ubong, A., Farinazleen, M.G., Cheah, Y.K. and Son, R. (2011) Salmonella: A foodborne pathogen. Int. Food Res. J., 18(2): 465-473.

5. Shinohara, N.K.S., Barros, V.B., Jimenez, S.M.C., Machado, E.C.L., Dutra, R.A.F. and Lima Filho, J.L. (2008) Salmonella spp., importante agente patogênico veiculado em alimentos. Cien. Saude Colet., 13(5): 1675-1683.

6. Abd El-Ghany, W.A. (2020) Salmonellosis: A foodborne zoonotic and public health disease in Egypt. J. Infect. Dev. Ctries., 14(7): 674-678.

7. Lobna, M.A.S., Maysa, A.I.A., Nashw, O.K. and Marwa, O.A.S. (2017) Zoonotic importance of salmonellosis in chickens and humans at Qualyobia province. Egypt. J. Vet. Sci., 47(2): 151-164.

8. Scallan, E., Hoekstra, R.M., Angulo, F.J., Tauxe, R.V., Widdowson, M.A., Roy, S.L., Jones, J.L. and Griffin, P.M. (2011) Foodborne illness acquired in the United StatesMajor pathogens. Emerg. Infect. Dis., 17(1): 7-15.

9. Anderson, T.C., Nguyen, T.A., Adams, J.K., Garrett, N.M., Bopp, C.A., Baker, J.B., McNeil, C., Torres, P., Ettestad, P.J., Erdman, M.M., Brinson, D.L., Gomez, T.M. and Behravesh, C.B. (2016) Multistate outbreak of human Salmonella Typhimurium infections linked to live poultry from agricultural feed stores and mail-order hatcheries, United States 2013. One Health, 2(12): 144-149.

10. Hansen-Wester, I. and Hensel, M. (2001) Salmonella pathogenicity islands encoding type III secretion systems. Microbes Infect., 3(7): 549-559.

11. Lerminiaux, N.A., Mackenzie, K.D. and Cameron, A.D.S. (2020) Salmonella pathogenicity island 1 (SPI-1): The evolution and stabilization of a core genomic type three secretion system. Microorganisms, 8(4): 1-22.

12. Jamshidi, A. (2009) Identification of Salmonella spp. and Salmonella Typhimurium by a multiplex PCR-based assay from poultry carcasses. Int. J. Vet. Res., 3(1): 43-48.

13. Lou, L., Zhang, P., Piao, R. and Wang, Y. (2019) Salmonella pathogenicity island 1 (SPI-1) and its complex regulatory network. Front. Cell. Infect. Microbiol., 9(7): 1-12.

14. Pham, O.H. and McSorley, S.J. (2015) Protective host immune responses to Salmonella infection. Future Microbiol., 10(1): 101-110.

15. Abdel-Aziz, N.M. (2016) Detection of Salmonella species in chicken carcasses using genus specific primer belong to invA gene in Sohag city, Egypt. Vet. World., 9(10): $1125-1128$
16. Yanestria, S.M., Rahmaniar, R.P., Wibisono, F.J. and Effendi, M.H. (2019) Detection of invA gene of Salmonella from milkfish (Chanos chanos) at Sidoarjo wet fish market, Indonesia, using polymerase chain reaction technique. Vet. World., 12(1): 170-175.

17. Malorny, B., Hoorfar, J., Bunge, C. and Helmuth, R. (2003) Multicenter validation of the analytical accuracy of Salmonella PCR: Towards an international standard. Appl. Environ. Microbiol., 69(1): 290-296.

18. Wibisono, F.J., Sumiarto, B., Untari, T., Effendi, M.H., Permatasari, D.A. and Witaningrum, A.M. (2020) Antimicrobial resistance on Escherichia coli from poultry production on Blitar, Indonesia. Indian J. Forensic Med. Toxicol., 14(4): 4131-4136.

19. Hale, C.R., Scallan, E., Cronquist, A.B., Dunn, J., Smith, K., Robinson, T., Lathrop, S., Tobin-D'Angelo, M. and Clogher, P. (2012) Estimates of enteric illness attributable to contact with animals and their environments in the United States. Clin. Infect. Dis., 54(5): S472-S479.

20. Behravesh, C.B., Brinson, D., Hopkins, B.A. and Gomez, TM. (2014) Backyard poultry flocks and salmonellosis: A recurring, yet preventable public health challenge. Clin. Infect. Dis., 58(10): 1432-1438.

21. Wibisono, F.J., Sumiarto, B., Untari, T., Effendi, M.H., Permatasari, D.A. and Witaningrum, A.M. (2020) The presence of extended-spectrum beta-lactamase (ESBL) producing Escherichia coli on layer chicken farms in Blitar area, Indonesia. Biodiversitas, 21(6): 2667-2671.

22. Widodo, A., Effendi, M.H. and Khairullah, A.R. (2020) Extended-spectrum beta-lactamase (ESBL)-producing Escherichia coli from livestock. Syst. Rev. Pharm., 11(7): 382-392.

23. Harijani, N., Oetama, S.J.T., Soepranianondo, K., Effendi, M.H. and Tyasningsih, W. (2020) Biological hazard on multidrug resistance (MDR) of Escherichia coli collected from cloacal swab of broiler chicken on Wet Markets Surabaya. Indian J. Forensic Med. Toxicol., 14(4): 3239-3244.

24. Wibisono, F.J., Sumiarto, B., Untari, T., Effendi, M.H., Permatasari, D.A. and Witaningrum, A.M. (2020) CTX gene of extended-spectrum beta-lactamase (ESBL) producing Escherichia coli on broilers in Blitar, Indonesia. Syst. Rev. Pharm., 11(7): 396-403.

25. Pemkab Blitar. (2018) General Description of Blitar District. Available from: http://www.blitarkab.go.id. Retrieved on 14-01-2021.

26. Effendi, M.H., Tyasningsih, W., Yurianti, Y.A., Rahmahani, J., Harijani, N. and Plumeriastuti, H. (2021) Presence of multidrug resistance (MDR) and extended-spectrum beta-lactamase (ESBL) of Escherichia coli isolated from cloacal swabs of broilers in several wet markets in Surabaya, Indonesia. Biodiversitas, 22(1): 304-310.

27. Rahn, K., Grandis, S.A., Clarke, R.C., McEwen, S.A., Galan, J.E., Ginocchio, C., Curtiss, R. and Gyles, C.L. (1992) Amplification of an invA gene sequence of Salmonella Typhimurium by polymerase chain reaction (PCR) as a specific method for detection of Salmonella. Mol. Cell. Probes, 6(4): 271-279.

28. Rahayuningtyas, I., Astuti, L.S., Istiyaningsih, I., Andesfha, E. and Atikah, N. (2018) Isolation and identification of Salmonella sp and Escherichia coli for mapping antimicrobial resistance in layer and broiler farms in 5 provinces in Java. In: Penyidikan Penyakit Hewan Rapat Teknis dan Pertemuan Ilmiah (RATEKPIL) dan Surveilans Kesehatan Hewan Tahun 2018. p482-494.

29. Thaha, A.H. (2016) Clinical description and prevalence of salmonellosis in layer chickens in Tanente village, Kec. Maritigae, Sidrap Regency. Lab. Basic Anim. J. (Ilmu Peternak Fak. Sains Teknol.), 3(1): 160-168.

30. Darmawan, A., Muslimin, L., Arifah, S. and Mahatmi, H. (2020) Contamination of Salmonella spp in broiler chicken sold in several traditional markets in Makassar. Indones. 
Med. Vet., 9(2): 168-176.

31. Eng, S.K., Pusparajah, P., Ab Mutalib, N.S., Ser, H.L., Chan, K.G. and Lee, L.H. (2015) Salmonella: A review on pathogenesis, epidemiology and antibiotic resistance. Front. Life Sci., 8(3): 284-293.

32. Magiorakos, A.P., Srinivasan, A., Carey, R.B., Carmeli, Y., Falagas, M.E., Giske, C.G., Harbarth, S., Hindler, J.F., Kahlmeter, G., Liljequist, B.O., Paterson, D.L., Rice, L.B., Stelling, J., Struelens, M.J., Vatopoulos, A., Weber, J.T. and Monnet, D.L. (2012) Multidrug-resistant, extensively drug-resistant and pandrug-resistant bacteria: An international expert proposal for interim standard definitions for acquired resistance. Clin. Microbiol. Infect., 18(3): 268-281.

33. Rahmahani, J., Salamah, S., Mufasirin, M., Tyasningsih, W. and Effendi, M.H. (2020) Antimicrobial resistance profile of Escherichia coli from cloacal swab of domestic chicken in Surabaya traditional market. Biochem. Cell. Arch., 20(1): 2993-2997.

34. Rahman, S.U., Ali, T., Ali, I., Khan, N.A., Han, B. and Gao, J. (2018) The growing genetic and functional diversity of extended-spectrum beta-lactamases. Biomed. Res. Int., 2018(3): 9519718.

35. Raini, M. (2016) Fluoroquinolones antibiotics: Benefits and side effects. Vol. 26. In: Pusat Penelitian dan Pengembangan Biomedis dan Teknologi Dasar Kesehatan, Badan Litbangkes, Kemenkes RI. p163-174.

36. Riwu, K.H.P., Effendi, M.H. and Rantam, F.A. (2020) A review of extended-spectrum $\beta$-lactamase (ESBL) producing Klebsiella pneumoniae and multidrug-resistant (MDR) on companion animals. Syst. Rev. Pharm., 11(7): 270-277.

37. Putra, A.R.S., Effendi, M.H. and Kurniawan, F. (2020) Investigation of extended-spectrum beta-lactamase (ESBL) Producing Escherichia coli by vitek-2 on dairy cows in Surabaya, Indonesia. Biochem. Cell. Arch., 20(2): 6773-6777.

38. Wibisono, F.J., Sumiarto, B., Untari, T., Effendi, M.H., Permatasari, D.A. and Witaningrum, A.M. (2020) Prevalence and risk factors analysis of multidrug resistance of Escherichia coli bacteria in commercial chicken, Blitar district. J. Trop. Anim. Vet. Sci., 10(1): 15.

39. Wibisono, F.J., Sumiarto, B., Untari, T., Effendi, M.H.,
Permatasari, D.A. and Witaningrum, A.M. (2020) Short communication: Pattern of antibiotic resistance on extended-spectrum beta-lactamases genes producing Escherichia coli on laying hens in Blitar, Indonesia. Biodiversitas, 21(10): 4631-4635.

40. Sofiana, E.D., Pratama, J.W.A., Effendi, M.H., Plumeriastuti, H., Wibisono, F.M., Hartadi, E.B. and Hidayatullah, A.R. (2020) A review of the presence of antibiotic resistance problems on Klebsiella pneumoniae acquired from pigs: Public health importance. Syst. Rev. Pharm., 11(9): 535-543.

41. Permatasari, D.A., Witaningrum, A.M., Wibisono, F.J. and Effendi, M.H. (2020) Detection and prevalence of multidrug-resistant Klebsiella pneumoniae strains isolated from poultry farms in Blitar, Indonesia. Biodiversitas, 21(10): 4642-4647.

42. Sharma, I. and Das, K. (2016) Detection of invA GENE IN ISOLATED Salmonella from marketed poultry meat by PCR assay. J. Food Proc. Technol., 7(3): 1000564.

43. Yulian, R., Narulita, E., Iqbal, M., Sari, D.R., Suryaningsih, I. and Ningrum, D.E.A. (2020) Detection of virulence and specific genes of Salmonella sp. indigenous from Jember, Indonesia. Biodiversitas, 21(7): 2889-2892.

44. Li, H., Bhaskara, A., Megalis, C. and Tortorello, M.L. (2012) Transcriptomic analysis of Salmonella desiccation resistance. Foodborne Pathog. Dis., 9(12): 1143-1151.

45. Pardo-Roa, C., Salazar, G.A., Noguera, L.P., SalazarEchegarai, F.J., Vallejos, O.P., Suazo, I.D., Schultz, B.M., Coronado-Arrazola, I., Kalergis, A.M. and Bueno, S.M. (2019) Pathogenicity island excision during infection by Salmonella enterica serovar Enteritidis is required for crossing the intestinal epithelial barrier in mice to cause systemic infection. PLoS Pathog., 15(12): e1008152.

46. Andhesfha, E., Indrawati, A. and Mayasari, N.L.P. (2019) Identification of Virulent Genes and Antibiotic Resistance Coding Genes in Salmonella Enteritidis from Layer and Broiler Farms in Java Island. Institut Pertanian Bogor, IPB Repository, Bogor, Indonesia.

47. Ansharieta, R., Effendi, M.H. and Plumeriastuti, H. (2021) Genetic identification of shiga toxin encoding gene from cases of multidrug resistance (MDR) Escherichia coli isolated from raw milk. Trop. Anim. Sci. J., 44(1): 10-15. 